\author{
李 炳 熙*1, 工藤一彦*1, 黒田明慈*1
}

\title{
Analytical Model of Radiative Heat Transfer through Fibrous Layer
}

\author{
Bingxi LI, Kazuhiko KUDO and Akiyoshi KURODA
}

\begin{abstract}
An analytical model is developed to calculate the radiative heat transfer through a fibrous layer with various fiber orientations consdering the effect of the diameter and the optical properties of the fiber. Milne-Eddington approximation is adopted to obtain a two-flux model type of formulation. To facilitate determination of the extinction efficiency, scattering albedo of the fibrous layer and backscatter factor required for the analysis, these values are shown graphically as the functions of complex index of refraction. size parameter and fiber orientation. The validity of the present model is shown by comparing the results with ones obtained by the Monte Carlo method.
\end{abstract}

Key Words: Thermal Radiation, Heat Transfer, Analytical Model, Fibrous Layer, Two Flux Model

\section{1. 緒言}

吸仪・散乱・自己放射性媒体を透過する放射エネル ギーの解析は, 各種断熱材の特性を調べるのに重要で あるが，媒体に扔ける散乱が等为散乱でない限り，散 乱による影響を正確に把握することはやっかいな問題 である、特に繊維のような円柱形状の物体における散 乱強度は，球状物体と違って入射角度と散乱角度の関 数であるため，さらにその放射位熱解析モデルの確位 が難しくなる。

Strong ら(1) おょび Davis-Birkebak ${ }^{(2)} ら は$, 実験 的に求めた緎維層の吸収係数あるいは放射率を用いて 熱流束を求める解析モデルを提案したが, 䄉維単体の 光学物性值，およびこれらの配向が一定で，繊維層厚 さ・織維の体積密度のみ変化する場合でも繰り返して 奏験を行って，吸収係数あるいは放射率を求める必要

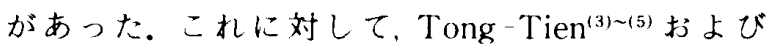
$\mathrm{Lee}^{(6)(7)}$ は、織維単体のサイズパラメータと複素屈折 率を与えることにより，電磁波理論により瀻維固有の 光学物性值を求め, これと織維の配向を用いて逆散乱

* 店稿受和 1995 年 4 月1211.

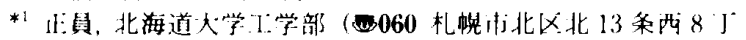
H).
割合を求め，二流束モデルを基本として，放射エネル ギー輸送式の解を求め, 織維層を透過する熱流束を求 めている。ここでTong-Tienの方法は，逆散乱割合を 求める解析を，織維層に垂值入射する放射工ネルギー に対してしか行っていないのに対し, Leeのち法は任 意の方向加人射寸る放射エネルギーに対しても解析 が四能となっている．しかしいずれの場合も、二流束 法の適用に際し, Schuster-Schwarzschild ${ }^{\left({ }^{(B)}\right.}$ 近似(以 ト S-S 近似と省略する)を使用しているため, 求めた 熱流束值が尖際の值に比べ過小に評価されることが示 されている(3).

またこれらの解析に必要な織維の光学物性值に関し ては，山田ら(9), 黑崎ら(10)の研究により, 複素屈折率 の得られてない織維についても, 繊維 1 本によって散 乱される光け強度分布の測定から，散乱断面積と位相

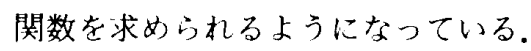

著者ら(11)は，織維層を透過する放射エネルギーの 方向分布を，正確に模擬できるモンテカルロ法を使っ て放射伝熱解析を行い, Tong-Tienのガラス織維を 湖いた実験傎とよくい致与る結果を得ている。モンテ カルロ法による解析は、让確な解を求めることはでき るが、計算時間が長く，緎維の光学物性值・配局・纎維 径のみならず，体積密度だけ変化する場合でも計算を 
やりなおさ极ばならず，実際の応用においては不便な ところがある.

そこで，本研究では従来の二流束モデルによる解析 を改良し，モンテカルロ法による計算結果との比較に よりそり妥当性を確認した。な抏，本研究では熱伝達 としては放射のみを考えることにした。

解析に用いた系は，一定の温度差をもつ 2 枚の無限 平行平板とここ机に挟まれた下記配列分布を有寸る織

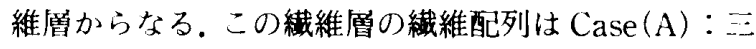
次元的にランダムに配列, Case (B)：平板に平行な面内 でランダムに配列，の2 種類を考えた。解析にあたり 平板は黒体とし，単一繊維の光学物性值はこれを川柱 と仮定して Kerker ${ }^{(12)}$ の電磁波理論により求めた(11)。

\section{おもな記号}

$b_{s}:$ 逆散乱割合

$e:$ 壁面放射エネルギー $\left(=\sigma T^{4}\right) \quad \mathrm{W} / \mathrm{m}^{2}$

$f:$ 単一散乱位相関数

$f_{v}:$ 体積密度

$I:$ エネルギー強度 $\mathrm{W} /\left(\mathrm{m}^{2} \cdot \mathrm{rad}\right)$

$m$ : 複素届折率 $(n-k i)$

$N_{s}$ : 単位体積当たりの織維の長さ $\mathrm{m} / \mathrm{m}^{3}$

$q$ ：単位時間に移動する熱量 $\mathrm{W} / \mathrm{S}$

$R:$ 織維半径 $\mu \mathrm{m}$

$T:$ 温度 $\mathrm{K}$

$Z_{L}:$ 縺維層の厚さ $\mathrm{m}$

$\Omega$ : 立体角 $\mathrm{rad}$

$\beta:$ 式(10)，(11)の係数

$\mu \equiv \cos \tau$

$\theta:$ 散乱角 $\mathrm{rad}$

$\sigma_{a}:$ 緎維層の平均吸収係数 $\mathrm{m}^{-1}$

$\sigma_{s}:$ 瀻維層の平均散乱係数 $\mathrm{m}^{-1}$

$\sigma_{e}$ : 瀻維層の平均隇衰係数 $\left(\sigma_{a}+\sigma_{s}\right) \mathrm{m}^{-1}$

$\tau:$ 天頂角 $\mathrm{rad}$

$v: x-y$ 平面に招ける方位角 $\mathrm{rad}$

$\phi:$ 入射角 $\mathrm{rad}$

$\omega:$ 瀻維層の散乱アルベド

添等

$i:$ 入射

$s$ : 散乱

$f:$ 織維

$b:$ 黒体

\section{2. 解析モテル}

図 1 に示される系において，吸収・放射・散乱性媒体 に扮ける単色放射エネルギーの輸送式は，下式で表さ

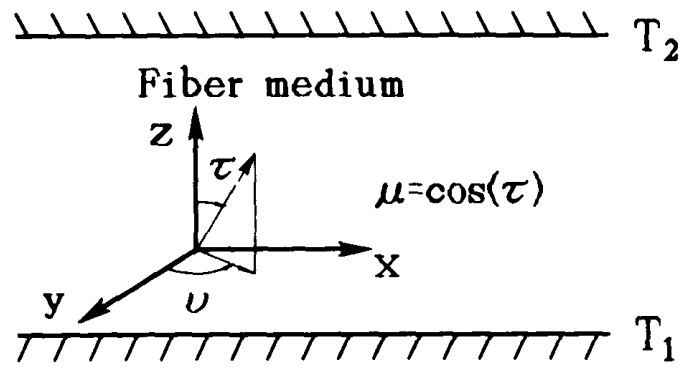

Fig. 1 Analytical model

れる。

$$
\begin{aligned}
& \frac{\mu d I(z, \mu, \nu)}{d z}=-\left[\sigma_{a}+\sigma_{s}\right] I(z, \mu, \nu)+\sigma_{a} I_{b}(T) \\
& \quad+\sigma_{s} \int_{4 \pi} f\left(\Omega^{\prime} \rightarrow \Omega\right) I\left(z, \mu^{\prime}, v^{\prime}\right) d \Omega^{\prime} \quad \cdots \cdots \cdots(1)
\end{aligned}
$$

$z$ 軸に垂直な瀻維風断面を透過する正負方向の放射 エネルギー強度が方向によらず一定だとし，正負方向 における放射エネルギ一強度をそれぞれ $I_{0}^{+}(z)(\mu \geqq$ $0), I_{0}^{-}(z)(\mu<0)$ とし, 二流束法の近似として熱流束 の計算に重みを招いた Milne-Eddington ${ }^{(13)}$ 近似(以 下 M-E 近似と略す) 者用いて式(1)を積分すると下 式が得られる。

$$
\begin{aligned}
& \frac{d I_{0}^{+}(z)}{d z} \int_{0}^{\pi / 2} \cos ^{2} \tau \sin \tau d \tau \\
& \quad=\int_{0}^{\pi / 2} \cos \tau \sin \tau\left\{-\left[\sigma_{a}+\sigma_{s}\right] I_{0}^{+}(z)\right. \\
& \quad+\sigma_{a} I_{b}(T)+\sigma_{s} \int_{\Gamma^{\prime}} f\left(\Omega^{\prime} \rightarrow \Omega\right) I_{0}^{+}(z) d \Omega^{\prime} \\
& \left.+\sigma_{s} \int_{U} f\left(\Omega^{\prime} \rightarrow \Omega\right) I_{0}^{-}(z) d \Omega^{\prime}\right\} d \tau \quad(1 \geq \mu>0)
\end{aligned}
$$

$$
\begin{aligned}
& \frac{d I_{0}^{-}(z)}{d z} \int_{0}^{\pi / 2} \cos ^{2} \tau \sin \tau d \tau \\
& \quad=\int_{0}^{\pi / 2} \cos \tau \sin \tau\left\{-\left[\sigma_{a}+\sigma_{s}\right] I_{0}^{-}(z)\right. \\
& \quad+\sigma_{a} I_{b}(T)+\sigma_{s} \int_{U} f\left(\Omega^{\prime} \rightarrow \Omega\right) I_{0}^{-}(z) d \Omega^{\prime} \\
& \left.\quad+\sigma_{s} \int_{\Gamma} f\left(\Omega^{\prime} \rightarrow \Omega\right) I_{0}^{+}(z) d \Omega^{\prime}\right\} d \tau \quad(0>\mu \geq-1)
\end{aligned}
$$

ここで, $I_{0}(z) \cos \tau$ は $z$ 軸に垂直な断面を透過する熱 流束に相当するものである。また ○、Uは入射の方向 $\Omega^{\prime}$ に対し, 散乱方向 $\Omega$ の $z$ 方向の成分が変わらない 場合と変わる場合について，それぞれ各方向の半球に 対する積分を表す。式(2)，（3）を積分し，式(6) 〜 (8)を用いて熱流束 $q$ に関する式に整理すると次 の上うな式が得られる。

$$
\frac{d q^{+}(z)}{d z}=-\frac{3}{2} \sigma_{a} q^{+}(z)-\frac{3}{2} b_{s} \sigma_{s} q^{+}(z)
$$




$$
\begin{aligned}
& +\frac{3}{2} \sigma_{a} e_{b}(T)+\frac{3}{2} b_{s} \sigma_{s} q^{-}(z) \cdots \cdots \cdots \\
& \frac{d q^{-}(z)}{d z}=-\frac{3}{2} \sigma_{a} q^{-}(z)-\frac{3}{2} b_{s} \sigma_{s} q^{-}(z) \\
& +\frac{3}{2} \sigma_{a} e_{b}(T)+\frac{3}{2} b_{s} \sigma_{s} q^{+}(z) \cdots \cdots \cdots .
\end{aligned}
$$

ここで、M-E近似で $I_{0}^{*}, I_{0}^{-}$が各半球内で一定だと仮 定しているので

$$
\begin{aligned}
& q^{-}(z)=\pi I_{0}^{-}(z), \quad q^{-}(z)=\pi I_{0}^{-}(z) \\
& e_{b}(T)=\pi I_{b}(T) \quad \ldots \ldots \ldots \ldots \ldots \ldots \ldots \ldots \ldots \ldots \ldots \ldots \ldots \\
& b_{s} \equiv \int_{b} f\left(\Omega^{\prime} \rightarrow \Omega\right) d \Omega^{\prime} \quad \ldots \ldots \ldots \ldots \ldots \ldots
\end{aligned}
$$

であり，ยっは黒体の放射エネルギーで，式(8)は逆散 乱割合を示す， $b_{s}$ の求め方は次章に記述する。また織 維層内に抢ける放射平衡より式(9)が得られる。

$2 \sigma_{a} e_{b}(T)=\sigma_{a}\left[q^{+}(z)+q^{-}(z)\right]$

式(9)を式(4)，(5)に代入して $e_{b}(T)$ を消去し, 整 理すると下式が得的机る。

$$
\begin{aligned}
& \frac{d q^{+}}{d \tau}=-\beta\left(q^{+}-q^{-}\right) \\
& \frac{d q^{-}}{d \tau}=-\beta\left(q^{-}-q^{-}\right) \\
& \text {ここで } \\
& \beta \equiv{ }_{4}^{3}(1-\omega)+\frac{3}{2} \omega b_{s} \\
& \omega \equiv \frac{\sigma_{s}}{\sigma_{e}} \\
& d \tau \equiv \sigma_{e} d z
\end{aligned}
$$

である、瀻維㕌の減衰係数 $\sigma_{\boldsymbol{e}}$ ，散乱アルベド $\omega$ の求め 方は次章に記述する。式(10)，(11）上り瀻維層を透過 する正味放射熱流束 $q$ はド式で表される。

$$
q=q^{*}-q=\frac{\left(e_{1}-\epsilon_{2}\right)}{\left(1+\beta \tau_{0}\right)} \quad\left(\tau_{0}=\sigma_{\epsilon} z_{l}\right)
$$

ここで

$$
e_{1}=q^{*}(z=0) / \pi, \quad e_{2}=q^{-}\left(z=z_{1}\right) / \pi
$$

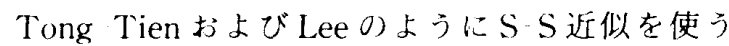

と、熱流束の式は式(15)と同じになるが，及の值が

$$
\beta=(1-\omega)+2 \omega b_{s}
$$

となり(3K7)、式(12)に比べてその傎大きくなり，し たがって式(15)により求められる熱流束の計算值が過 小評価されることがわかる。

\section{3. 逆散乱割合 $b_{s}$ と $\sigma_{e}, \omega$ の計算}

逆散乱割合 $b_{s}$ とは，正半球方们に响かうすべての 人射エネルギーの散乱のうちで，負半球㹝向に向かう 散乱エネルギ一の割合，あるいは負半球方向に向かう 入射エネルギーのうちの正方向への散乱割合である。 式(15)より放射熱流束を計算寸る際には， $\sigma_{\boldsymbol{e}}$ と係数 $\beta$ を求める必要があり，また式(12)より及を計算するた

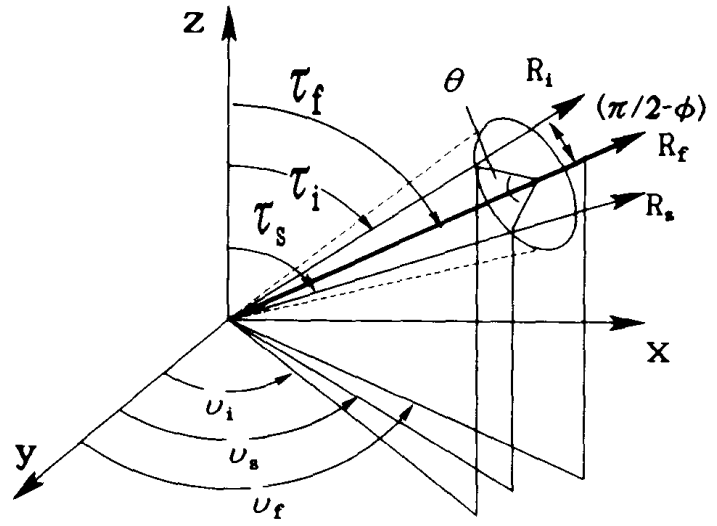

Fig. 2 Scattering by single fiber

めにはまず逆散乱割合 $b_{s}$ と散乱アルベド $\omega$ を計算し なければならない。戍 2 に三次元空間に配列された単 一緎維に扔ける散乱形態を示す。ここで， $R_{i}, R_{s}, R_{f}$ はそれぞれ入射㧍よび散乱エネルギーの方向，緎維の 配列方向を表し， $\tau$ は天頂角， 0 は $x, y$ 平面における 方位角， $\phi$ は人射光と繊維中心軸の垂線となす角(入 射角)で，その求め方は前報(11)に示した。また $\theta$ は散 乱角を表す。織維が $x y$ 平面に平行な面内でランダム に配列さ机たCase（B)の場合には，すべての入射方向 に対して逆散乱が存在するのに対し，絨維が空間にラ ンダムに配列されたCase (A) 0)場合は，逆散乱が存在 するためには，最大散乱夫頂角 $\tau_{s, \max }$ が $\pi / 2$ を超える 必要があり，図3に亦されるように三つの種類が考え られる。ここで， $Z$ 軸に平䘕な而向からみた人射工ネ ルギーと纎維のな方角 $\left|v_{i}-v_{f}\right|$ が $\pi / 2$ より小さい場命 では，戍3(a)に亦すように散乱円錐面が織維の力后 とつねに同方向となるが, $\left|v_{i}-v_{f}\right|$ が $\pi / 2$ より大きい

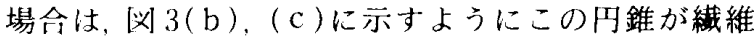

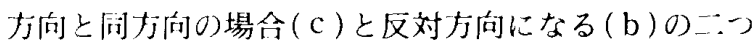
に分加れ。.Case（a)，(c)の場合は $\tau_{s, \max }=\tau_{f}+\phi_{c}$ $>\pi / 2$ となり, Case (b) 0)場命は $\tau_{s, \max }=2 \pi-\tau_{f}-\phi_{c}$ $>\pi / 2$ となる。ここで， $\phi_{c}$ は入射エネルギーと瀻維の 中心軸のなす角である。 Lee ${ }^{(7)}$ の報告には（c）の場合 が甹まれていないため，bsの計算值が実際の値より小 さくなる。

式(8)中の泣体角 $d \Omega^{\prime}$ は入射エネルギー分布を図 10xy唒に行な黑体壁面からの放射エネルギ ーと同じくランベルト余弦則に従う尔布を有するとす ると

$d \Omega^{\prime}=\sin \tau_{i} \cos \tau_{i} d \tau_{i} d v_{i}$

となる。また，瀻維が空間でランダムに配列された Case (A)の場合に, 織維の分布は $\sin \tau_{f} d \tau_{f} d v_{f}$ とな る。したがって，単一䄉維の散乱位相関数 


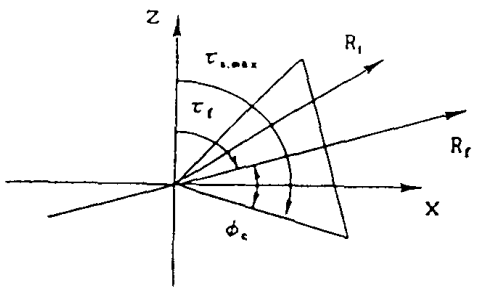

(a) $\left|v_{i}-v_{j}\right|<\pi / 2$

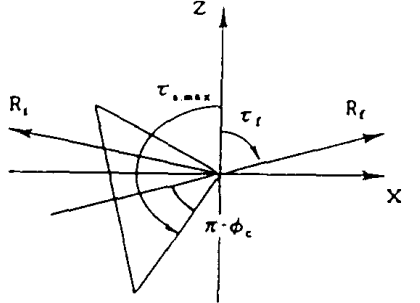

(b) $\left|v_{i}-b_{f}\right|>\pi_{i}, 2, \phi_{c}>\pi_{i} / 2$

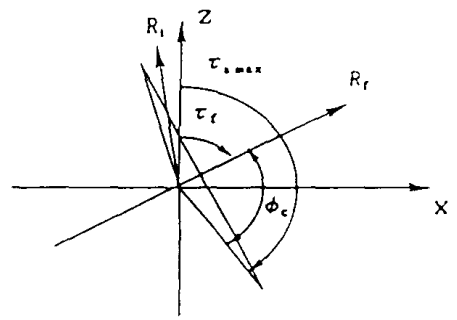

(c) $\left|b_{i}-b_{y}\right|>\pi / 2, \phi_{C}<\pi / 2$

Fig. 3 Backscattering conditions

$I_{s}(\phi, \theta) d \theta / \int_{0}^{2 \pi} I_{s}(\phi, \theta) d \theta$

を用いると，立体角 $d Q^{\prime}$ の人射エネルギーに対する散 乱位相関数㳉

$$
\begin{aligned}
f\left(d \Omega^{\prime} \rightarrow \Omega\right) d \Omega^{\prime} \\
=\frac{\int_{0}^{\pi / 2} \int_{0}^{2 \pi} I_{s}(\phi, \theta) \sin \tau_{f} d \Omega^{\prime} d v_{f} d \tau_{f} d \theta}{\int_{0}^{2 \pi} \int_{0}^{\pi / 2} \int_{0}^{2 \pi} I_{s}(\phi, \theta) \sin \tau_{f} d \Omega^{\prime} d v_{f} d \tau_{f} d \theta} \\
=F(\phi, \theta) d \theta \ldots \ldots \ldots \ldots \ldots \ldots \ldots \ldots \ldots \ldots . \ldots \ldots \ldots \ldots \ldots \ldots
\end{aligned}
$$

となり、ここで式(18)のように $F(\phi, \theta)$ を定義し，後 述の $\theta_{1}, \theta_{2}$ を用いると，立体角 $d Q^{\prime}$ の入射エネルギー に対する逆散乱割会は

$$
b_{s}^{\prime}=\int_{\theta_{1}}^{\theta_{2}} F(\phi, \theta) d \theta
$$

となる。したがって，エネルギー透過の正半球力向の 入射エネルギーに対する逆散乱割命は式(8)より

$$
\begin{aligned}
b_{s} & =\int_{0}^{\pi / 2} \int_{0}^{2 \pi} \int_{0}^{\pi / 2} \int_{0}^{2 \pi} \int_{\theta 1}^{\theta 2} I_{s}(\phi, \theta) \sin \tau_{f} \sin 2 \tau_{i} \\
& \times d \theta d v_{f} d \tau_{f} d v_{i} d \tau_{i} /\left\{\int_{0}^{\pi / 2} \int_{0}^{2 \pi} \int_{0}^{\pi / 2} \int_{0}^{2 \pi} \int_{0}^{2 \pi}\right. \\
& \left.I_{s}(\phi, \theta) \sin \tau_{f} \sin 2 \tau_{i} d \theta d v_{f} d \tau_{f} d b_{i} d \tau_{i}\right\}
\end{aligned}
$$

となる。

Case (B)の配列の場含は $\tau_{f}=\pi / 2$ であるため,

$$
\begin{aligned}
& b_{s}=\int_{0}^{\pi / 2} \int_{0}^{2 \pi} \int_{0}^{2 \pi} \int_{\theta 1}^{\theta 2} I_{s}(\phi, \theta) \sin 2 \tau_{i} \\
& \times d \theta d v_{f} d v_{i} d \tau_{i} /\left\{\int_{0}^{\pi / 2} \int_{0}^{2 \pi} \int_{0}^{2 \pi} \int_{0}^{2 \pi}\right. \\
& \left.I_{s}(\phi, \theta) \sin 2 \tau_{i} d \theta d v_{f} d v_{i} d \tau_{i}\right\}
\end{aligned}
$$

となる。また繊維層の隇衰係数 $\sigma_{e}$ と散乱アルベド $\omega$ は, 式 (20)，(21)中の $I_{s}(\phi, \theta)$ の代わりに $2 R \cdot N_{s} \cdot Q_{\text {ext }}(\phi)$ あるいは $\omega(\phi)$ を代入することにより 求められる。ここで䄉維への放射エネルギーの入射角 $\phi$ は $\left(\tau_{i}, v_{i}\right)$ と $\left(\tau_{f}, v_{f}\right)$ より求められ, 単一織維の散乱 エネルギー強度 $I_{s}(\phi, \theta)$, 隇镜効率因子 $Q_{\text {ext }}(\phi)$ 上散 乱アルベド $\omega(\phi)$ は文献 $(12) ，(13)$ 電磁波理論によ り求められる。ここで繊維朔断面を透過する放射工ネ

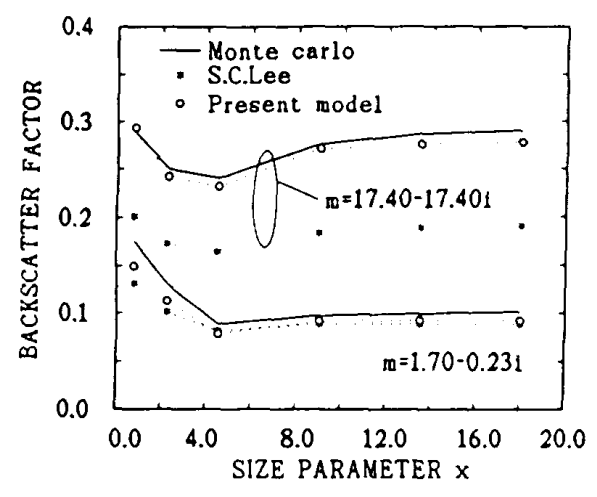

(a)

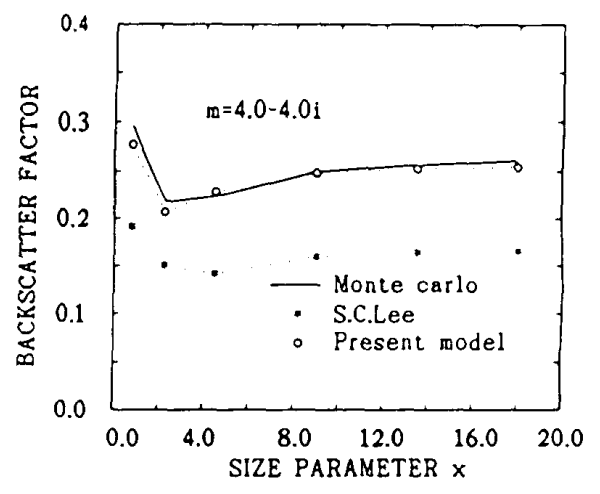

(b)

Fig. 4 Backscatter factor in Case (A)

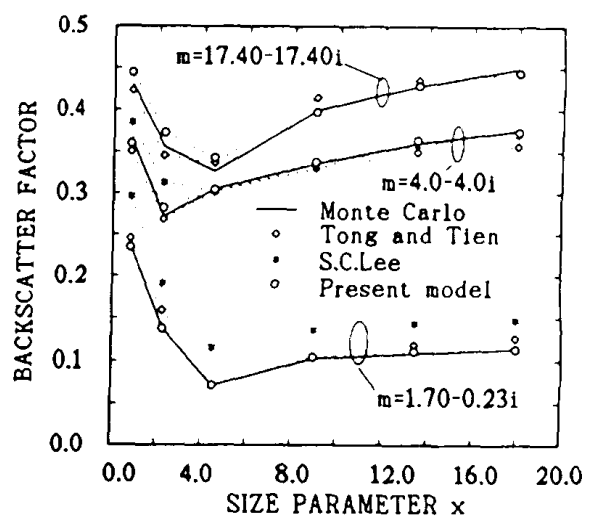

Fig. 5 Backscatter factor in Case (B) 
ルギーの方向分布に関しては, Case (B)の場合におい てはランベルト余弦則による分布と近い分布であ り(11)，またCase（A)の場合にも同じ傾向を示すこと がわかった。しかし Lee ${ }^{(7)} の$ 解析では, 放射エネルギ 一の方向分布がガス放射のように等方的だとしている ため, 式(20)，(21)中の $\sin 2 \tau_{i}$ 項が $\sin \tau_{i}$ となってい る。 $\theta_{1}, \theta_{2}$ は図 2 に示さ机る散乱们錐面をその直角断 面で划った阿とその中心を通る $x y$ 平面と平行な平 面との二つの交点を考えたとき，仩上でのこの二つの 交点と问上での入射エネルギーの透過点の間のな寸角 である. $\theta_{1}, \theta_{2}$ の求め方は Lee ${ }^{(7)}$ の報告で詳述されてい るため, 省略させていただきたい。应 4,5 に壁面から 射出された放射工ネルギーが絨維層で散乱されるとき の逆散乱割合の計算に関して, Tong-Tien ${ }^{(5)}$, Lee $^{(7)}$, 本文の式(20)，(21) 抢よびモンテカルロ法による解析
結果を示寸。図 4 は Case (A) 0場合で，本文の式 (20) を用いた解析結果がモンテカルロ法による解析結果と よく一致することが示されている. Leeによる解析結 果がかなり小さいのは，図 3 中でのCase（c）が抜け ているためである.Case(B)の場合でも図うに示され ているように，本文の式(21)を用いての解析結果とモ ンテカルロ法による解析結果がよく一致することがわ かる。一无 Tong-Tienの計算では，すべての入射角に 対して， $\theta=\pi / 2 \sim 3 \pi / 2$ を逆散乱範囲と指定し，また Leeの場合は人射エネルギー分布を等方だと指定した ため，モンテカルロ法による解析結果と若斗違う值を 示している。

また式(20)，(21)0計算はやっかいであるため, 式 (20)，(21）を用い，広い範册のサイズパラメー夕，䄉 維の配列, 複素届折率に対して逆散乱割合, 織維層の
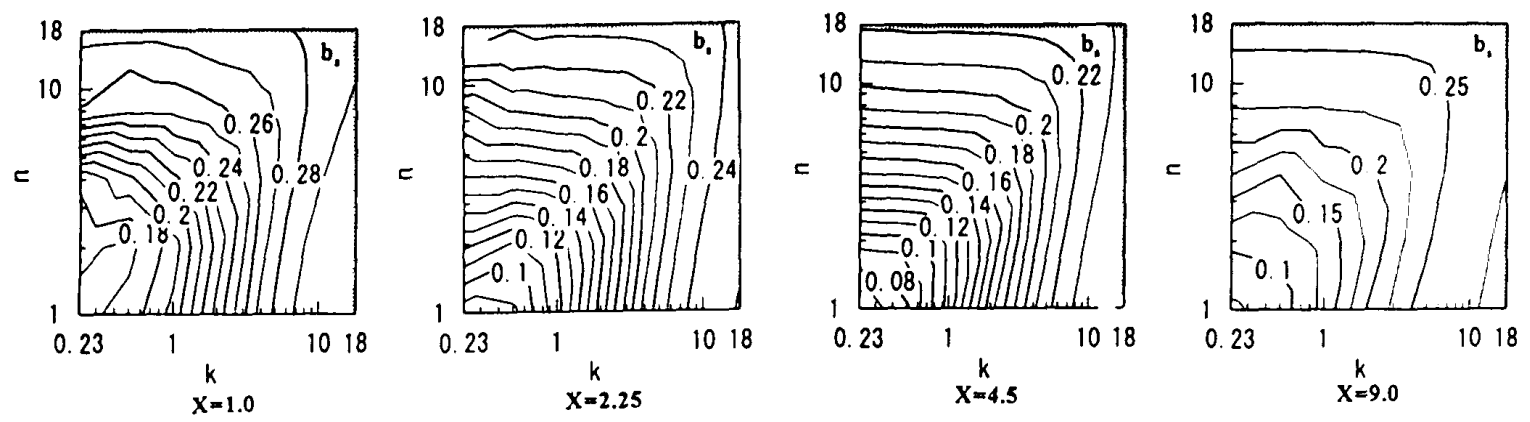

Fig. 6 Effects of complex refractive index on backscatter factor [Case (A)]
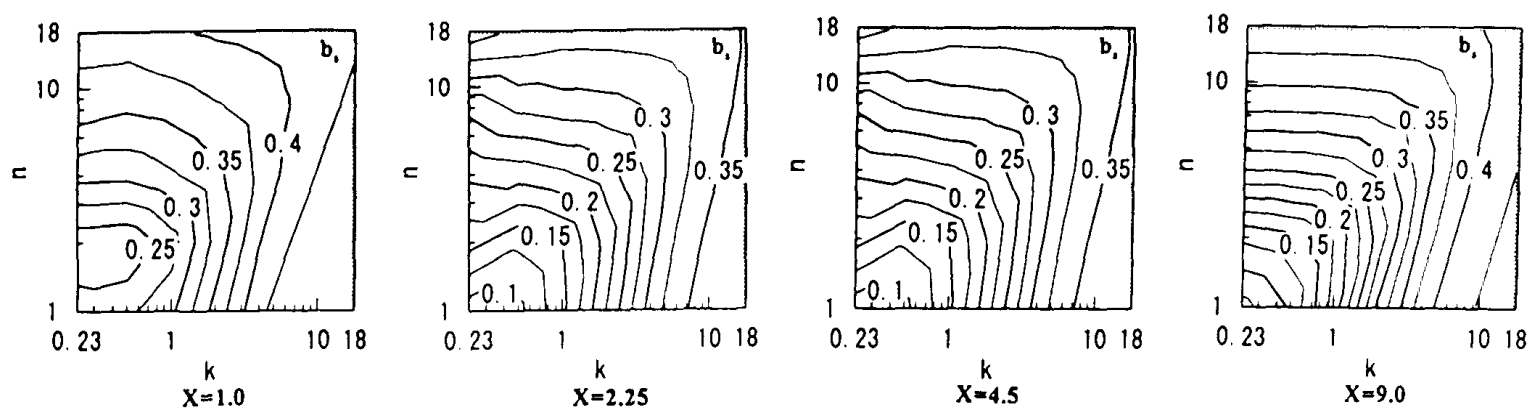

Fig. 7 Effects of complex refractive index on backscatter factor [Case(B)]
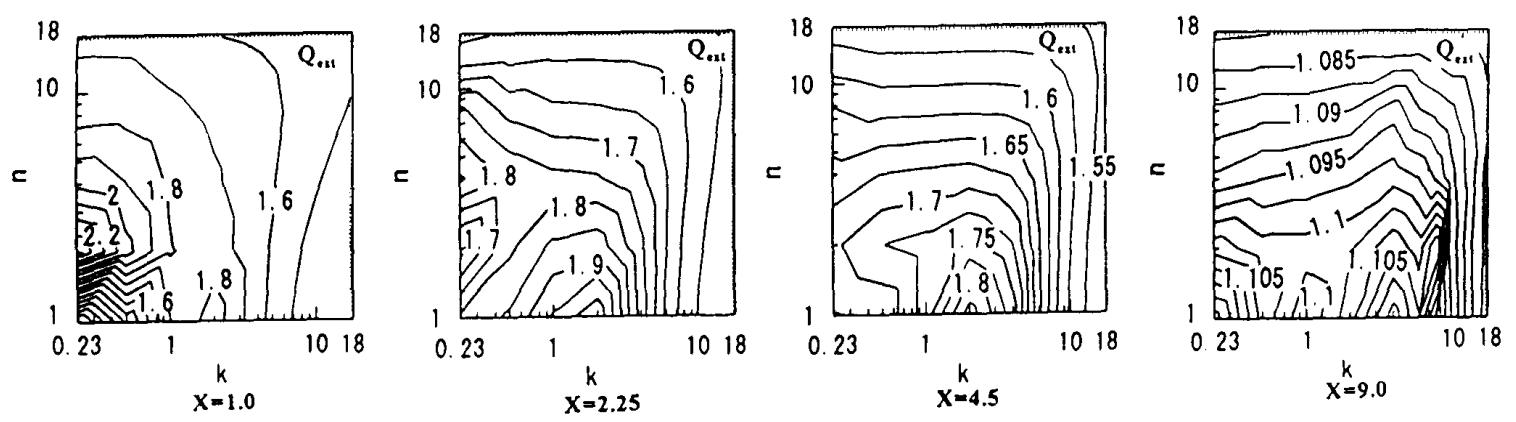

Fig. 8 Effects of complex refractive index on extinction efficiency [Case(A)] 

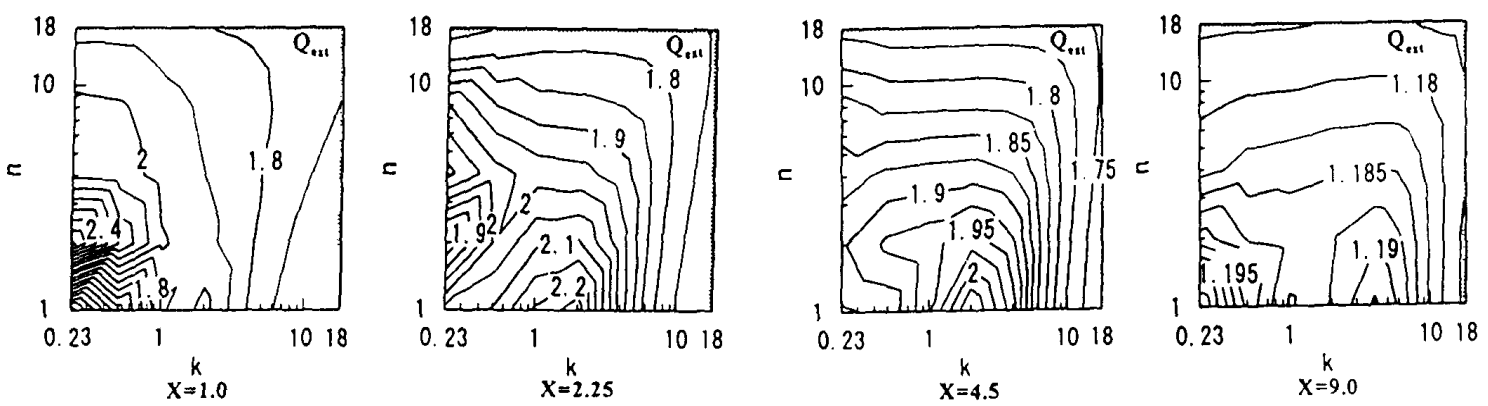

Fig. 9 Effects of complex refractive index on extinction efficiency [Case(B) :
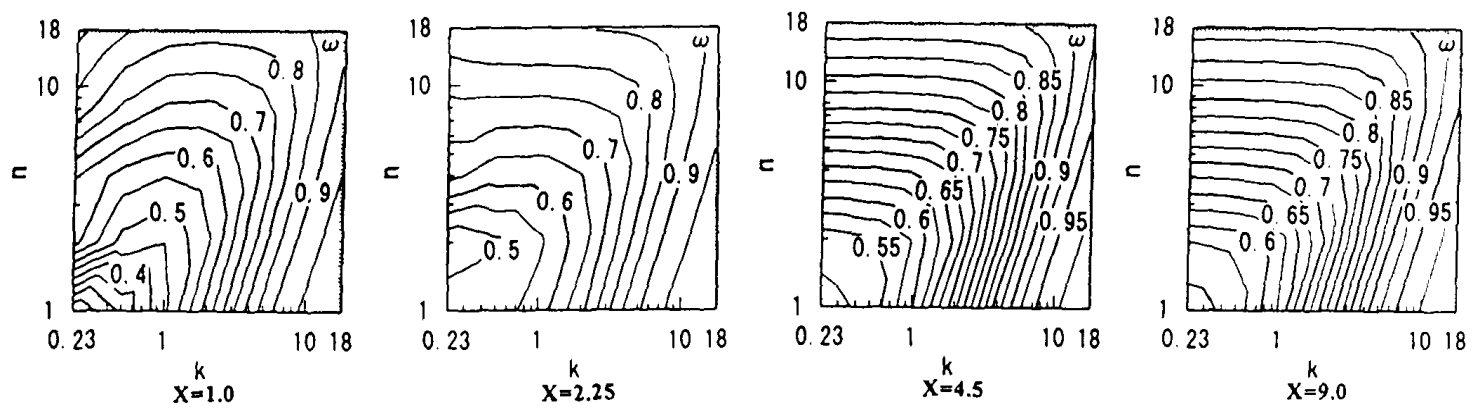

Fig. 10 Effects of complex refractive index on Scattering albedo [Case (A)]
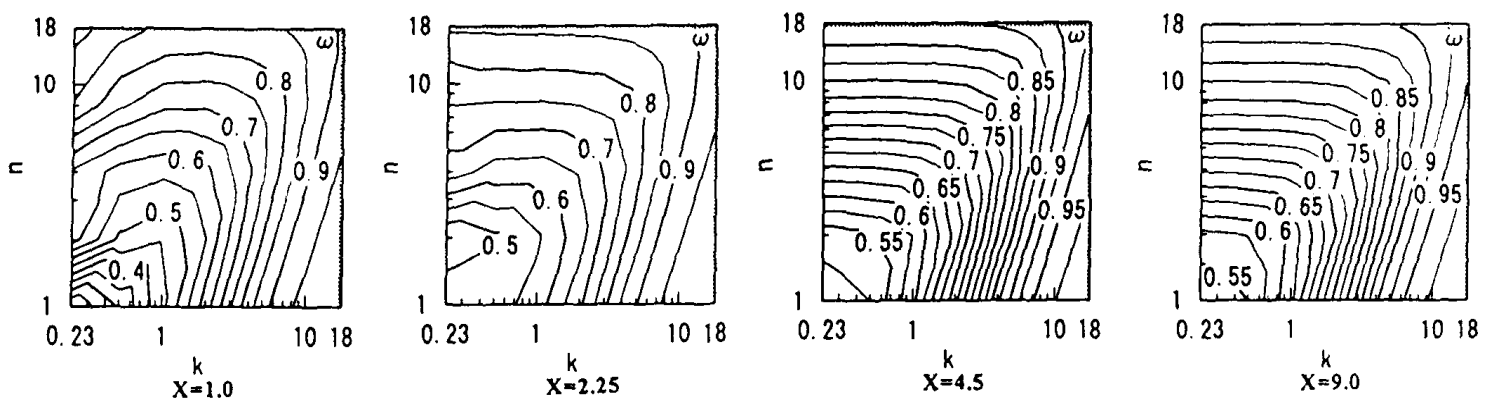

Fig. 11 Effects of complex refractive index on Scattering albedo [Case $(\mathrm{B})$ ]

堿衰俰数および㵶維層の散乱アルべドを求めたのがそ れぞれ図 6〜11である。以上の解析から本研究のよう な系に打いては，織維のサイズパラメー夕，配列，複 素屈折率がわかれば，式(20)，(21)あるいは図 6〜11 を用いて, 逆散乱割合 $b_{s}$ と減衰係数 $\sigma_{e}$, 散乱アルベ ド $\omega を$ 求めることができる。

\section{4. 壁面熱流束の解析}

モンテカルロ法による解析手法 ${ }^{(1)}$ の開発で, 繊維 層を透過する放射熱流束を正確に求めることができる ようになったが，実際の応用ではある程度の精度をも ちながらより計算時間が短く、簡単な計算方法が必要 である、そこで，本研究ては二流束法に基ついた新し い解析モデルを開発したが、本解析モデルの妥当性を 検討するために，本解析モデルと Tong Tien, Lee モ
デルによる瀻維層透過放射エネルギーの解析結果と, モンテカルロ法による解析結果を比較した。ここで式 (12)と（17）の比較のため, 壁面熱流束の計算において, Tong-Tien, Lee モデルによる計算でも, 逆散乱割合 $b_{s}$ は式 (20)，(21)(あるいは図 6,7)を用いて求めた值 を使うことにした。

図 12 にはC Case(A)織維配列の場合, 図 13 には Case (B)緎維配列の場合に対して，瀻維のサイズパラ メータ, 無次元層厚さ, 複美屈折率を変化させたとき の解析結果を示す.Case (A)の場合において, 図 12 に 示されているように，いずれの場合でも本解析モデル による計算值がモンテカルロ法による解析結果に近い 值を示し，S-S 近似によるLeeの解析結果が実際值よ り過小評価されることがわかる。また，本解析モデル による計算結果が, 全体的にモンテカルロ法による計 


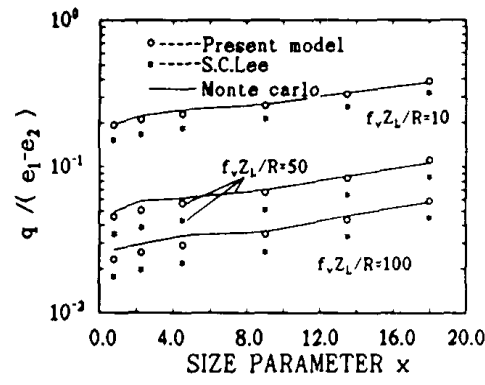

(a) $m-17.40 \div 17.40 i$

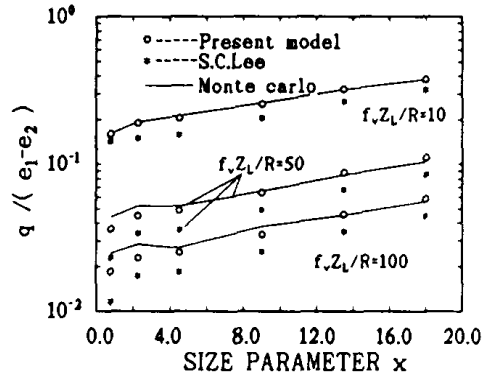

(b) $m=4.0-4.0 i$

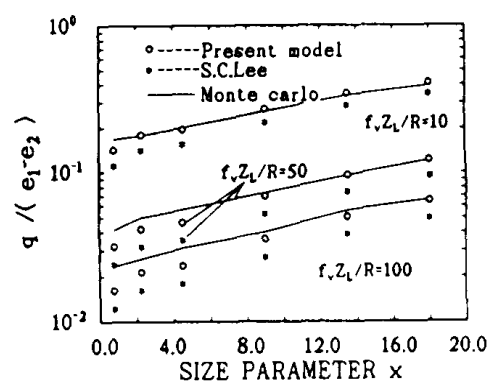

(c) $m=1.70-0.23 i$

Fig. 12 Wall heat flux in Case (A)

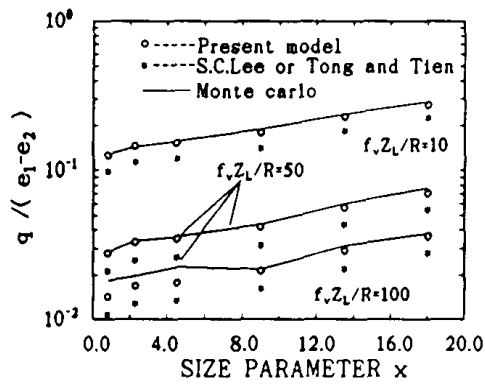

(a) $m=17.4-17.4 i$

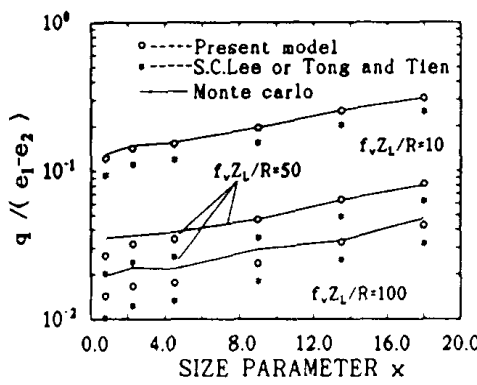

(b) $m=4.0-4.0 i$

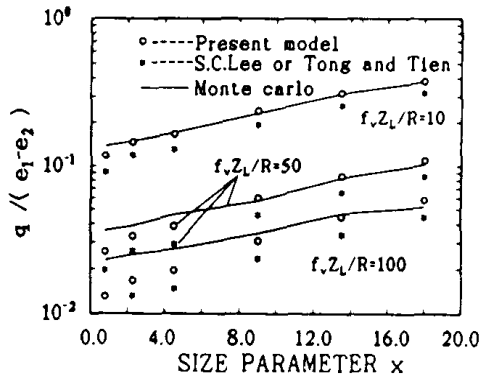

(c) $m-1.70-0.23 i$

Fig. 13 Wall heat flux in Case (B)

算結果よりやや低い值を示しているが，これは解析モ デルにおいては，緎維層を透過する放射エネルギー強 度の方向別分布が角度によらず一定だと仮定したのに 対して，実際に織維層を透過する放射エネルギー強度 の方向別分布がこれより获汗前方に偏った分布を示す ためであると考えられる(11). 特に、絨維のサイズパラ メー夕，複素阵折率が小さく，無次元層原さが大きい ときに，その傾向が大きくなることがわかる. Case (B) の場命でも図 13 に示すように，本解析モデルによ る計算值が Tong TienあるいはLee モデルより，モ ンテカルロ法による解析結果に近い值を示すことがわ かる.また, Case (A)の場合と同じく, サイズパラメー 夕, 複素届折率が小さく，無次元層厚さが大きいとき に本解析モデルによる計算值とモンテカルロ法による 計算值の差が大きくなることがわかる，以上の解析か ら，M-E近似による二.流束法を用いた本解析モデル による熱流束の計算值が，モンテカルロ法による計算 值に近いことが示され，本解析モデルの妥当性が確認 された。

\section{5. 結西}

平行平板に挟まれた瀻維層における放射エネルギー の透過に関して、流束法による新しい解析モデルを 開発し、モンテカルロ法による計算結果との比較によ
りその妥当性を確認し，以下のような結論を得た。

（1） M-E近似を用いた二流束法を用い，また緎 維層内を透過している放射エネルギーの方向分布と織 維の配向分布を考虑して求め大逆散乱割合を用いるこ とにより、瀻維層を透過する放射熱流束に関し，モン テカルロ法による計算值とよい一致を得ることができ た.

（2）上䛉解析に必要な逆散乱割命，瀻維層の減衰 係数と散乱アルベドを，公い範卧のサイズバラメー 夕・複素届折率扝よび 2 種類の瀻維配列に対して求め, グラフ化することにより，繊維層の放射エネルギー透 過解析の実用化をはかった。

\section{文献}

(1) Strong, H, . . and Bundy. F. P., J. Appl. Phys, 311 (1960), 39

(2) Dais, I. B. and Birkebak, R. C.. Biophys. J., 14(1974), 449

(3) Tong, T.W. and Tien, C. L., Trans. ASME, J. Heat Transf., 105(198:3), 76

(4) Tong, T. W. and Tien. C. L., J. Ther. Insu., 4(1980)), 27.

(5) Tong. T. W. and Tien, C. L., Trans. ASME, J. He'at Trunsf.. 105(1983), 70).

(6) Lee, S. C., J. Thermophysics, 24 (1988), 303.

(7) Lee. S. C.. Int. J. Heat Mass Transf. 33 10(1990). 2183.

(8) Siegel, R. and Howell, J. R., Thermal Radia. Heat Trunsf. (1972), 491, New York. 
(9) 山H純 - 黑㱦晏尖, 機論, 57-541，B(1991)，3213.

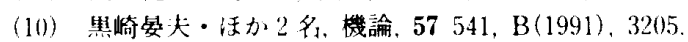

(11) 1滕一陔・活加4名，機諭，61582，B(1995)，679.

(12) Kerker, M. The Scattering of Light, (1969), 265 ,
Academic Press

(13) Van de Hulst. H.C., Light Scattering by Small Parti cles, (1981), 306. New York. 